\title{
THE CONSEQUENCES OF THE SIN AT THE LEVEL OF HUMAN MIND, WILL, AND SENTIMENT AND OF FREEDOM AND CONSCIOUSNESS
}

\author{
Prof. PhD. Marin BUGIULESCU, \\ Professor, Director of "Saint John Chrysostom" Orthodox Theological Seminary, Târgovişte, \\ Member of „Dumitru Stăniloae ${ }^{e e}$ Scientific and Interdisciplinary \\ Research Centre, Valahia University, Târgoviște, \\ ROMANIA \\ Email: m_bugiulescu@yahoo.com
}

\begin{abstract}
This article presents the moral impact of sin on man and society. The modern man does not have as features spiritual and moral balance. The notion of sin has begun to be used more often with reference to the environment in which man lives, not only to the human person. In contrast to classical definitions, which considered sin to be a personal, intimate lack of relationship with God or others, in a more or less bilateral manner, the climate involution and the general state of the environment determined the theologians and problem specialists of ecology to speak of sins against the environment.
\end{abstract}

Keywords: sin; perfection; Christianity; man and society;

\section{INTRODUCTION}

Man was born freely, having the power to obey or not God's will from the beginning. The Creator made the compassionate beings that He created with the opportunity to move voluntarily and freely, so that they could acquire good features for themselvs which they would preserve by their own will. In fact sin is the centering of man in himself, through which the powers of soul, reason and will are dominated by the senses or the body. By sin, man has departed from God, from his fellow kind and from his own self. The dynamism of the image of God in the man from the original state due to sin is passive. Because of this, human nature has undergone a series of degrading transformations that end up fatally with death.

The Concept of the Holy Fathers on Sin, according to the biblical account (see below chapter 3), considers sin to begin with the rebellion of angels against God, but subjectively it is founded on the liberty with which human kind was endowed. The original human nature has in itself the power of life, "posse non mori", and the power of purity "posse non peccare", but not all of it, which enables it to connect with God and communicate with God on the basis of a genuine relationship. If God had created the perfect human, then the human would have had no merit for his perfect condition, and if He had created him altogether sinful, then man would not have been able to reach to perfection and God, in this case, would have been the author of evil. The Holy Fathers argue that just as deification is possible only for rational and free beings, so is the sin made only by these beings: angels and men.

One of the fundamental questions is related to the occurrence of evil. Who is the source of evil? God or man? 
Logically and ontologically God is the Supreme Being, therefore, he cannot be counted as the author of evil, because He would contradict his goodness, his love, and his absolute perfection. Both angelic beings and human beings have been created and endowed with rational and free will, so they have their own decision-making power, which enables the disposition to evil. The autonomy of angels and men reveals that God is not the author of evil, but rational and free beings, who make decisions without any constraint, both towards good - God and evil - inexistence.

As for the sensus and theological implications, sin is distinguished from other notions such as imperfection, passion, crime, evil, selfishness and sensuality, notions that are closely related and often confused. Thus, sin is distinguished from imperfection, which is the lack or denial of a following moral goodness, since it is not a free and conscious violation of the law. Also, sin is different of passion or vice, because sin is an act, while passion is a steady activity in action that contravenes moral law. Sin is also different from the offense that constitutes the external violation of the law. Therefore, any sin is also sin, but not every sin is also an offense, because sin can involve not only external but also internal aspects. As far as the notion of evil is concerned, it is wider than sin. Sin is the moral evil, the worst of evil and the cause of all the other misdoings, but cannot be identified with what is meant by physical evil, which is punishment for sin and metaphysical evil. Sin is conscious and free transgression of the moral law, or conscious and free opposition to the will of God, expressed in moral law. But the complete definition of sin itself is this: Sin is the transgression of God's law, and this transgression is the very opposition to the will of God made with the mind and the will of the transgressor. The transgression of the divine law is done either by omission or by commitment, and consists of a work of thought, talk, or deed.

\section{PRIDE THE FIRST SOURCE OF SIN}

The fall of angels and men into sin is based on the same reason, namely pride ( $\varphi \imath \lambda$ ó $\iota \mu о)$ or self-love. The angel, a spiritual being, who sees the glory of God, focused out of pride on its self-existence, gaining though eternal non-existence as an ontological state. From the point of view of Christian ontology, God is the source of all existence. Taking into account the high spiritual state in which the angels were, the punishment received by the act of evil was eternal and irrevocable, unable to be changed in any way, because after their fall into sin they were established by God according to their will in good - good angels and in evil - evil angels, having no other means of temptation. The punishment of man is also eternal, but revocable, because sin and the breaking of God's will were made under the temptation of evil angels. The fall of angels was explained by patristic theology as a means of rebellion and envy, which makes: "The demon, the beginner of the wickedness, seeing man become an angel on earth, was consumed by envy because he who had spent between the higher powers had been thrown down from that height because of its evil desire ... so he used ... the serpent, which surpassed in wisdom all the animals created, ... as a tool, and through it deceived the unguarded vessel, the worst, that is, the woman ..."

The biblical account of the ancestral history of sin begins by emphasizing the wisdom of the serpent that deceives the woman. The biblical serpent is a mask of the evil angel or the devil. About the fall of the angels, St. John Chrysostom formulates the teaching that the good angel has become evil, that is, "he lost his worth before the creation of the first one, because he thought he could be greater than he was (Sol. 2, 24 - looking at the greatness of man -...

\footnotetext{
${ }^{1}$ St. Ioan Gură de aur, Omilii la Facere, XVI, 1, trans. Pr. D. feciorul , in P.S.B. 21, Bucharest, 1987, p. 177
} 
they have conspired against him death. That is how wickedness is! It cannot bear quitely the happiness of others!"2 The Devil (Satan), as St. Basil the Great depicts him, is the adversary (II Kings 11:14): "He is called a devil, for he is both a sinner and an accuser of sin... His purpose is leadership, as the apostle: "Against the ruler who controls the darkness" (Ephesians 6:12) his leadership is exerted around the earth" ${ }^{3}$.

The Sacred Scripture presents the humans' temptation and fall into sin (Genesis 3: 12-24), first of all the woman tasting from the forbidden tree, then the man; as well as the banishment from Heaven. The devil promises man that he will be like God, knowing good and evil (Genesis 3: 5). St. John Chrysostom says, "Have you seen the devil's cunning? He said what God had not told them, to make the woman say what God had said to them (verses 2-3), so entrusted that the serpent speaks to her as a friend, she revealed the whole commandment, and told him everything, and so by answering the serpent, the woman deprived herself of any word of defense" ${ }^{4 .}$

By committing sin, the thinking of the humans which is existentially oriented towards the intelligible is dominated by the body. The taste of the tree of knowledge of good and evil awakens in the body of the human, the senses and pleasure, the concupiscence (Genesis 3: 6 ). The biblical opening of the eyes that sees the nakedness and awakens passionate appetites. For the first humans it was the time of alienation from God. As for the taste from the biblical tree, we can say that it did not open their eyes, because the humans could see before too, but it in that state it did not have any thoughts to deceive the command and the will of the Creator. By opening our eyes, as Saint John Chrysostom shows, we must understand that "the eyes of the mind have been opened to them ... understand that it made them feel their nakedness and that they had fallen from the glory they were before. ${ }^{5}$

In the Holy Scripture, sin has several meanings: the removal of purpose (Rom.5, 12), the failure to obey the law (I John 2: 2 Peter 2: 6), disobedience (Genesis 2:16, Romans 5:19) fall (Mark 11: 26), rebellion, or any act contrary to God. Etymologically, the term «sin» comes from the Hebrew words: hattat - removal of purpose, which corresponds to the Greek word adikia or the Hebrew word pesah - Greek anomia - revolt, rebellion; or from ebr. rasah - gr. kakopoiein - to hurt, in Latin, peccatum has a very wide meaning, i.e. any mistake. But, regardless of the meanings used, sin presents itself as a contrary will, removal from God, being freely done, because man: "abusing the natural power given to him by creation towards the union of the separated, he considered better to separate the united"6. The emergence of sin is firstly connected to the world of reason or mind. Thus sin has first of all an intellectual aspect. "The throne of the divine is the mind, and the throne of the mind is God and the Spirit, therefore it is said that Satan and his powers and beginners of darkness have settled, from the transgression of commandments, in the mind and heart of Adam as on their own throne... "7.

Patristic thought presented the process of conception of sin that takes place in several stages $^{8}$. Hesychius the Monk counts four: the attack, the accompaniment, the consensus, the sensitive deed, and St. John Damascene seven steps: the attack, the accompaniment, the passion, the struggle, the bondage, the conscience, the perpetuation. From all these moments,

\footnotetext{
${ }^{2}$ Ibidem, XX, II, p. 261

${ }^{3}$ St. Vasile cel Mare, Omulii şi cuvântări, IX, IX , trans. Pr. D. Feciorul in P.S.B. 17, Bucharest,1986, p. 444

${ }^{4}$ St. Ioan Gură de Aur, op.cit. XVI, III,p.179

${ }^{5}$ Ibidem XVI, V, PG. 184- 185

${ }^{6}$ St. Maxim Mărturisitorul Ambigua , trans. Pr. D. Staniloae, in P.S.B, Bucharest, 1983, p.236

${ }^{7}$ St. Macarie Egipteanul, Omilia VI,V, Pr. Prof Constantin Corniţescu, P.S.B. 80, Bucharest, 1992, p.123

${ }^{8}$ Pr. D. Stăniloae, Ascetica şi mistica, I,5, Bucharest, 2002, p. 114
} 
the most decisive is where our thinking has its attitude. 1. The attack belongs to the Satan and is accomplished by temptation, - the time of the temptation of the woman, (Genesis 3: 15). The bait is shed wisely by the snake, it brings the evil thought to the woman, thought which is like a confusing image, it would have been natural for her to turn her back on it and run away. 2. Accompanying, at this stage the human thought takes on a simple form and interferes with the thought thrown by Satan. Referring to the first humans, Adam and Eve, the woman discusses with the devil, as the biblical account tells us more, is convinced by him that she will become like God: "the mind being darkened by those promised, it makes its thoughts to give a form to the pleasure, because it is without image and form according to its reason ... " 9 . At this stage we enter the dangerous area of sin. 3 . Consciousness makes the notion of evil appear in the mind, the simple thought is visualized, now the inner passion appears: "the woman, considering that the fruit of the tree is good to eat, and pleasing to the eyes ..." (Genesis 3: 6). The sensitive act transposes the visual thought outward, now is the sin, and once it is done it manifests itself like a chain requiring another sin, which through exercise becomes a passion or a vice (Face 3: 6), the woman falls, tempting the man, and so sin repeats itself.

The etymology of the passionate word comes from the Greek patio and the Latin passio,-onis which means bondage, passivity. Reason, the human mind through passions is dominated by the impulse of matter, and that is why it manifests itself duplicitously.

"So much sin has spread that the soul has been forced to follow the wills of the body; I forced the soul, who ought to stand the first as a master, and command, I forced him to descend from the throne and obey the pleasures of the body, I no longer took account of his nobility and his great rank. .."10.

Sin is the irrational start that gripped all human nature. St. Maximus the Confessor believes that the first sin is pride, and consists in selfish love, from which all other sins and passions are born. The possibility of the birth of passions is given by the existence of natural affections, which are: "the condemnable and contrary beings that hang upon us do not have any source in us other than in the movement of affections according to nature" ${ }^{11}$, they have degenerated into the human nature with the fall into sin, dwelling on its less rational side, not part of the original constitution of man. We can say that in the original state there was a kind of affection or passion of spiritual pleasure, but it did not enslave the nature but was a real state of being, it was the real mode of existence, reason, conscience and freedom, increasingly centered in the immense divine - theonomy.

The affections added to the human nature by sin in themselves are not condemnable if they are kept within the natural boundaries, as long as it is necessary for them to exist. They characterize the fallen state of the human being, being related to leather garments (Genesis 3:21), and they become good in those who strive and tear them apart wisely of the flesh to acquire the heavenly goods. If they are satisfied, then they destroy the unity of the human being, the man reaching autonomy and self-sufficiency. Archimandrite Justin Popovich in connection with them says, "What is the chief and most important thing for the life of man? Undoubtedly, to give meaning to his life, which from the ontological and phenomenological point of view became meaningless because of death, that is, of $\sin ^{\prime 12}$. This centering, autonomy of man in itself, embodied in the illusive thirst for the absolute, backed

\footnotetext{
${ }^{9}$ St. Maxim Marturisitorul Ambigua., p. 107

${ }^{10}$ St. Ioan Gură de Aur, Omilii la Facere XII,V, p.145

${ }^{11}$ St. Maxim Mărturisitorul, Quaest ad. Thalas P.G., 90,541

${ }^{12}$ Arhim Iustin Pooivici, Omul şi Dumnezeu- omul, I, trans. Ioan Ică Jr., ed. Deisis, Sibiu 1997, p.44
} 
by the idea that he can become God, is contrary to all of the communion and love to which man is called; it places man and God in radically different realities, there is no possible connection between the divine and the human.

\section{EVIL DOES NOT HAVE NATURE IT IS AN ACCIDENT AND NOT A SUBSTANCE}

The essence of evil lies in the lack of good, for evil has no ontological existence, but is a state of adversity to virtue. The nature of evil appears as an accident that man adds to his nature, but the accident cannot be the same as the substance, for then there would be no accident or substance. The author cannot be God, because then all His perfection is contradicted; therefore evil has no existence, being the opposite of the idea of good not in the sense that evil exists in itself but is conceived as a lack of the manifestation of good. Manifestation of evil takes the form of good, it is disguised as good, therefore, and the fruit of the forbidden tree caused the pleasure of the flesh, and urged the first woman to taste and feel a good state of affection, but beneath this pleasure was hidden the pain . Dante Alighieri in the "Divine Comedy" says: hell is paved with good intentions (Infernal II, 127-129), that evil always bears the apparent mask of good. So if we leave the premise that evil has been from the beginning in the world is equivalent to treating God as the author of evil. Evil has entered the world through will and without a nature, but a state.

St. Gregory of Nyssa, speaking of the tree of the knowledge of good and evil, says, "The tree from which we gather mixed knowledge is part of the forbidden trees. Instead, his fruit, the defender of which has become the snake, is a mixture of contradictions, perhaps because, according to his nature, evil is not offered to us directly. For if evil does not leave traces so bad, it would not have been adorned with the label of good, in order to awaken the lusts in the ones he deceived. This is how the evil was presented in a shrouded way, but ... he hid, the destruction of human ... he shows the image of the good "13. The interpretation given by St. Maximus to the two trees in heaven highlights the fact that evil, once fed by the human nature, lowers man's attention to the material and sensitive: "As long as man has come into existence, made up of the soul of the mind, and of the flesh endowed with senses, according to a first sense, the tree of life is the mind of the soul, in which the wisdom has its seat, and the tree of knowledge of good and evil is the sensation of the body, in which it is obvious that the irrational movement is impelled. ."14.

The fact that man could have sinned is linked to the free will with which he was endowed, and to his dual nature, which had two movements, one ascending soul-related, and one descending of the flesh. Human freedom, standing in the middle between these two, is the force that decides the choice of good or evil. Thus, the first man desiring the bodily lusts has mastered the evil state that destroys the human nature. The beginning and root of sin lies in the nature of man, and especially in the freedom of the will. Evil, in relation to human nature, has caused pain and suffering that ends logically and ontologically with death.

The poems in prose of Baudelaire emphatically express man's relation to the defining of demons. "The devil's most beautiful chastity is to convince us that he does not exist." And if it does not exist, the question arises, why does man fear him? In humanistic thinking, this state is thus conceptualized: God existence: "I am the One who is". The devil is the seemingly degrading existence: "I am called nobody, there is nobody here, why are you afraid? Tremors in the face of nonexistent?"

\footnotetext{
${ }^{14}$ St. Maxim Mărturisitorul, Ambigiua.43, P.G. 90, 412-413

${ }^{15}$ Denis de Rougemont, Partea diavolului, trans. Mircea Ivănescu, Anastasia, Bucharest,, 1994, p. 11
} 
Man was created in the image of God, therefore in the ontological definition the original state was good, but the transformation inserted by sin made possible the corruption, the pain and the death. The gravity and the consequences of sin are seen from the very first moment of the transgression of the divine commandment, by sin the first men have known the effects of concupiscence: "Then they opened their eyes to both of them, and knew that they were naked and sewed fig leaves they have covered themselves"(Genesis 3: 7). The sense of emptiness, lack of existential sense, showed them that they lost the glory in which their image, the eikon was enveloped (man created in God's image). The shame that overwhelmed them was the measure of pleasure that had taken place in their nature, and reason and conscience had perverted themselves. In the biblical man subjected to sin "was the consciousness that the gaze of the other who falls on me is not the gaze of the one who loves me, in which I trust. It is the look of a stranger that does not look at me with love, but it sees me as an object of its desire and pleasure. Looking at the other, turning me into a neutral individual ..." $"$. The feeling of nakedness and shame also reveals the sense of guilt, now consciousness works and puts sin before the first humans, Adam feels fear and fear for what has been done, and shows cowardice, weakness, that is why he is hiding. Adam's fear is accentuated by God, who walks through Heaven in the cool of the evening (Genesis 3: 8), not because he did not know where man is, but to make man more aware of sin, what has happened now the righteous judge - the consciousness that awakens and shows them the magnitude of the sin committed; But instead of responding with dignity to the Creator, man is hiding from God who is everywhere. But psychologically, the voice of the Creator's love asks: "Where are you, Adam?", as he calls today the fallen human, and discuss with him through biblical teaching about what has happened. Man does not have the sense of responsibility, dignity, tries to blame the woman, and the woman on the snake. After this essential moment, God throws the curse upon men and the whole earth, and also announces a Savior to lift man to lost dignity (Genesis 3:15).

Another direct consequence of the ancestral sin is the change of the bright garment with the garments or the skins of the skins, the body (Genesis 3:21). Leather clothes, in the concept of Sacred Parents, represent the grasp of sin, which made the first men feel the unspeakable shame, but also the altered form in which death entered into human nature. St. Gregory of Nyssa, in this sense, says, "By a movement of our free will we have become partakers of evil, mixing it in our nature through the pleasure of the pleasure ... we have transformed ourselves into the image of the evil one ..., after the first humans were cast out of heaven, the Master covered them with leather garments. I do not think that Moses is thinking of the animal skins as we have imagined, for ... the skin separated from the animal to which it belonged is a dead thing, so the possibility of dying, which was taken wisely from the nature of the unbelievers, then threw it upon men, but not forever ... because the coat is something outside us, an object that has temporal use but has nothing to do with our nature. Death ... has embraced the outer nature of this nature, not the inner nature ... without touching the very image of God in man ... "17. Of course, the body clothed with the leather garments, becoming dense and solid, carnal, but with it, the psychic functions became fleshy. In the sense of Saint Gregory of Nyssa, the leather garments are the concrescent carnal consciousness that appear with the entrance of sin into human nature, because: "the coming to evil comes from not outside force, but as soon as we choose the evil, it takes existence,

\footnotetext{
${ }^{16}$ Christos Yannaras, Abecedar al credinţei, XI, trans. Pr. C. Coman, Bizantină, Bucharest, 1996, p. 103

${ }^{17}$ St. Grigore de Nyssa, Despre Facerea omului. VIII, p. $41-43$
} 
making itself when we choose it"18. Panayotis Nellas, says: "Therefore, if one wants to fully understand his existence, the good and the terrifying elements that whip him, man needs to broaden his horizon, ask himself if what he thinks is natural, is not as seems to be .... So we understand why, for the Saint Bishop of Nyssa, in this irrational biological, irrational, deadly carnalness, the honors man finds are inevitably ephemeral ... the certainties of the flesh are murderous, that is, death and death bringing. "19 According to Aglaofon, anyone who realizes that the body is extinguished and returns to the dust, Methodius of Olympus, responds firmly: "The body is between corruption and incorruptibility; he, who was the being of innocence, inclined to the dust of the earth." ${ }^{20}$ The death of the flesh (according to Methodius of Olympus) has the following purpose in God's plan after falling into sin: "This is the meaning of the leather tunics, clothed in them, the body is clothed in corruption, so that with it sin to be destroyed entirely "21 and thus the body be raised out of corruption by the resurrection of Christ.

St. Macarius the Egyptian teaching about the human being in the flesh says: "the clothing that you wear another has made ... so also Adam transgressing the commandment ... he sold himself to the devil, and the cunning clothed his soul ... for the soul mixes with those with which he unites by will ... "22, and St. John Chrysostom, speaking of the garment of leather, says that he has changed the bright garment of the image, and that were given to man by divine love, so that he does not live naked and it would differ from the clothes of the ungodly, but at the same time to remember the loss of good things in Heaven. ${ }^{23}$ Ioannis Zizioulas and Christos Yannaras conceive the human person as the reflex of divinity, which has three hypostases in history. The natural hypostasis in the state of grace, the biological hypostasis given by the human being in leather clothes, whose psychosomatic energies are serving life as the energy of individual ${ }^{24}$ survival and the ecclesiastical hypostasis achieved through the incorporation into Christ in the Church. ${ }^{25}$

The orientation of human to itself, the ontological autonomy and imprisonment by God's disobedience is the being of ancestral sin and is based on pride. Pride has begun the passions that enslave the human nature and make it deal with those without spiritual sense. After St. Maximus, the state of passivity that characterizes the fallen nature, is reduced to objectification, the thirst for knowledge, and the desire for infinity manifests itself in passions to the contrary, and so the whole human perspective becomes a world of objects; but the objects are by their nature finite because they are circumscribed and thus the satisfaction received is limited, and ends tragically in nonexistence by consuming them.

The greatest consequence of $\sin$ is death because "the consequences of $\sin$ is death" (Romans 6:23). By sin, man breaks the relationship with the source of life-God, losing the living grace of life, and thus receives the corruption that alters the glow of the image. All these consequences are the material aspect of the ancestral sin. Sin added to human nature becomes a second person for man, that is why it is accomplished with great ease, the nature being bent on sin, towards those that lead to death and non-existence.

\footnotetext{
${ }^{18}$ St. Grigore de Nyssa, Despre fericiri, trans. Pr. D. Stăniloae, in P.S.B. 29, Bucharest, 1982, p. 372

${ }^{19}$ P. Nellas, Omul, animal îndumnezeit, trans. Ioan Ică Jr., ed. a II- a, Deisis, Sibiu 1999, p. 85, 90

${ }^{20}$ Metodiu de Olimp, Despre înviere, XVIII, trans. Pr. Prof. C-tin Corniţescu, in: PSB. 10, Bucharest, 1984, p. 186

${ }^{21}$ Ibidem, XL, p. 150

${ }^{22}$ St. Macarie Egiptenul, Omilia.,I, VII,VIII, p. 90

${ }^{23}$ St. Ioan Gură de Aur, Omilii la Facere, I; XVIII,II, p. 209

${ }^{24}$ C. Yannaras, Abecedar al credinţei, p. 112

${ }^{25}$ Ioannis Zizioulas, Fiinţa eclesială, trans. by Pr. Aurel Nae, Bizantină, Bucharest, 1996, p. 46-79
} 
The formal aspect of the original sin and guilt for sin places human responsibility in divine justice. The problem of transmitting sin to Adam's descendants is one of the very controversial themes of theological debates, for which several theories have been elaborated, more less satisfactory, of which we mention:

1. The theory of the indirect imputation of original sin. The sin is present in the human nature shared by the descendants of Adam as a mood for evil. This theory removes human consciousness and freedom.

2. The theory of external imputation that the descendants of Adam are guilty of simply being descended from him. This theory is groundless because sin is not only imputed but also real and personal.

3. Naturalistic theory; based on the text of (Romans 5:12), according to which Adam the universal man concentrates in himself the whole human nature of all time. Neither can this theory be accepted because sin belongs to the person who hypothesizes the nature, and therefore the responsibility for it lies with every person.

4. The theory of sin is ancestral to human nature. This theory claims that blame is inherited in nature, but this is also not grounded because moral responsibility lies with personal consciousness and liberty.

5. The Theory of aligation - Instills a judgment of God through which a moral bond has been established between Adam's sin and the will of his descendants, but is not grounded because it contradicts the freedom of each human person.

Adam's sin is personal, but since the way his descendants come into existence is linked to sin, each person portrays the fallen nature, not Adam's before sin, the human nature having the afflictions of the fall, which in they are not condemnable, but they become accusatory if they are satisfied beyond what is necessary.

The aspect of punishment of sin manifests itself in many ways in the human nature, resulting ultimately in death. Death encompasses all humanity, for: "By one error came the chastisement of all men." (Romans 5:18). Adam's fall in $\sin$ is universal; therefore, the consequences extend to all people as descendants. "In fact, leaving Adam out of heaven, all creation ... seeing him more willing to obey the disobedient ... (the nature was lacking help from the uncreated energies from above that had retracted) ... seeing the naked man of the glory that was initially bestowed they despised him and stumbled against him ... "26.

The transmission of the ancestral sin is related to the way of Adam's descendants coming into existence. The fall in sin being included in the divine plan of creation, allowed man another way to share the supportive face of existence, that is, the birth. Adam came to existence through creation, and his descendants through birth: "For the first creation is called genesis and not genisis. Genesis is the first creation of God; but the birth is the succession of one another as a consequence of condemnation to death because of the transgression of the commandment ..." 27 Through the man - Adam it has been received the image of incomprehension, of impiety, and the new man receives the God's image altered by sin, the broken part of the flesh, the affections, the ability of suffering, but not Adam's sin and personal guilt. Of all men, only Adam has the faculty; his descendants come into existence by birth. Birth brings to man the fallen nature, so what man is born with the ancestral sin: "In sins my mother gived birth to me." (Psalm 50: 6), as the Psalmist says. Birth is seen as the means by which nature exists, a means of its perpetuation; that is why it produced much joy

\footnotetext{
${ }^{26}$ St. Simeon Noul Teolog, Cuvântări morale, I, trans. Pr. D. Stăniloae, in: Filocalia, vol. VI, Bucharest, 1977, p. 128.

${ }^{27}$ St. Ioan Damaschin, Dogmatica, XXX, trans. Pr. D. Fecioru, Bucharest, 2001, p. 110.
} 
to Adam, who did not know what would happen to his nature, which was going to death: "the birth of the heirs was the greatest comfort for the loss of the nation, it could be said that through this God outlined a picture of the resurrection, ordering others to rise instead of the dead ... "28. Birth is the means by which the Savior Christ assumes the fallen human nature, and Adam's made nature. By rehabilitating the fallen nature and filling with grace the made one, being the New Adam in which all are born for eternal life.

Adamic sin has the same form, with the sin committed by every man, and results in the lack of grace and life implication, but other content, for example, the sin of Cain as it is narrated by Scripture, has the same form as that of the forefathers but the curse, his punishment, is much greater, because it is the devil's tool through which death enters the world, even though it was "born in the image of God" (Genesis 5,3-5), which shows that man remains the image of God and after the receipt of corruption, the image being indelible, even if by sin man no longer has life as his constitutive characteristic, he no longer exists because of the life that naturally escapes from him, his life $(z o \bar{e})$ has changed into blind battle for survival (epiviose). Sin contains in body the one nature (John 3: 6), and the human race receives death as God's law for the transgression of the divine commandment. But in order for man to escape from the punishment of the law and death, God is made a true man, sharing through His resurrection, the likeness, the one created in the ikon, the God's image in the humans, destroying the sin and the neadle of death, through death defeating death, bringing together that which were apart, filling them with His great glory.

\section{CONCLUSION}

Christian morality deals with living and applying Christian teachings. Sin is an illusion of existence. According to the form of realization, sin is of two kinds: ancestry and personal. Ancestral sin is considered an anomaly at the level of genuine reality for which man was created. Sin by consequence manifests itself: intellectual, moral and religious. Personal sin is the sin committed by human as a result of the orientation of his free will to evil or to a seeming good that disregards the moral law. It may be present when the transgression or omission of the law is done in a single, habitual way when it is a sinful state that lasts.

The measure of the gravity of sin is given by several aspects:

1. the importance of the unconquered command, which encompassed the entire moral law;

2. the ease with which it was done at the urging of the wicked;

3. the punishment dictated by God's justice: death and other serious consequences.

The consequences of the ancestral sin are both spiritual and physical in nature. Of the spiritual ones, it is proper to state that on the soul, the ancestral sin meant:

1. Breaking the holy communion with God and altering the original state, the loss of love and grace, and thereby the spiritual death of man, in fact is the loss of the original perfection, the power of the soul, and the alteration of God's image in man.

2. The darkening of the mind, which immediately confuses good with evil. $\mathrm{He}$ believed he could hide from God, and that he could exonerate himself, blaming Eve and, indirectly, God.

3. Perversion of the heart, which has become more inclined to the worldly and sensitive, following the lusts of the body and changing the love of God with love for the creature.

${ }^{28}$ St. Ioan Gură de Aur, Omilii la Facere. XVIII, IV, p. 214. 
4. The weakening of the will that it follows the path of passions with ease, creating a permanent tension between different tendencies of human in his earthly life.

The greatest consequence of sin is death because "the punishment of sin is death" (Romans 6:23), because by sin man breaks the relationship with the source of life-God, losing his life-giving grace, and thus receives the corruption that alters the glory image. The consequences of sin are the alteration of the divine image of human, which darkens the mind, weakens the will, and perverts the human nature, but reflects on the entire creation.

The fall of man into sin produces both cosmological and anthropological disorder, because sin disrupts and destroys by death all existences, leading them into non-existence through hedonistic and irrational pleasures, which don't have real purpose.

\section{BIBLIOGRAPHY:}

[1]St. John Damascene, Dogmatica, (Dogmatics), trans. Pr. D. Feciorul, Bucharest, 2001

[2]Denis de Rougemont, Partea diavolului, trans. Mircea Ivănescu, Editura Anastasia, Bucharest, 1994.

[3] Sfântul Grigore de Nyssa, Despre Facerea omului, [About man's creation], trans. Pr. T. Bodogae, in: P.S.B. 30, Bucureşti 1998.

[4]Sfầntul Grigore de Nyssa, Despre fericiri, trans. Pr. D. Stăniloae, in: P.S.B. 29, Bucharest, 1982.

[5]Sfântul Ioan Gură de Aur, Omilii la Facere, trans. Pr. D. feciorul , in: P.S.B. 21, Bucharest, 1987.

[6]Sfântul Macarie Egipteanul, Omilii, Pr. Prof Constantin Cornițescu, P.S.B. 80, Bucharest, 1992.

[7]Sfântul Maxim Mărturisitorul, Ambigua , trans. Pr. D. Staniloae, in: P.S.B., Bucharest, 1983.

[8]Metodiu de Olimp, Despre inviere, [About resurrection] trans. Pr. Prof. C-tin Corniţescu in: P.S.B. 10, Bucharest 1984.

[9]Nellas Pannayotis, Omul, animal indumnezeit, trans. Ioan Ică Jr., ed. a II- a, Deisis, Sibiu 1999.

[10] Pooivici Arhim Iustin, Omul şi Dumnezeu- omul, I, trans. Ioan Ică Jr., Deisis, Sibiu 1997

[11] Simeon Sfântul Noul Teolog, Cuvântări morale, trans. Pr. D. Stăniloae, in: Filocalia 6, Bucharest, 1977

[12] Stăniloae Pr. D., Ascetica şi mistica, I,5, Bucharest, 2002.

[13] Sfântul Vasile cel Mare, Omulii şi cuvântări, trans. Pr. D. Feciorul in: P.S.B. 17, Bucharest, 1986.

[14] Yannaras Christos, Abecedar al credintei (Elements of Faith: An Introduction to Orthodox Theology) a.trans. Coman Constantin, Bizantină, Bucharest, 1996.

[15] Zizoulaslas Ioanis, Fiinţa Eclesială, (Being as Communion), Bizantină, București 2000. 